рішень. Тому в процесі підготовки до гри ми звертали увагу на усвідомлення iі учасниками необхідності єдності рольової і власної поведінки.

Отже, організація комунікативно спрямованого навчання дозволяє в умовах варіативності навчального спілкування формувати у студентів готовність до комунікативної діяльності.

\title{
Література
}

1. Андреева Г. М. Общение и оптимизация совместной деятельности / [под редакцией Г. М. Андреевой, Я. Яноушека] - М. : МГУ, 1987. - 302 с. 2. Бабанский Ю. К. Педагогика / Ю.К. Бабанский. - М. : Просвещение, 1998. - С. 345-365. 3. Бодалев А. А. Психологические трудности общения и их преодоление / А.А. Бодалев // Педагогика. - 1992. - № 5,6.- С.77-81. 4. Бутенко Н. Ю. Комунікативні процеси у навчанні: [підручник] / Н. Ю. Бутенко. - К.: КНЕУ, 2004 - 383 с. 5. Волкова Н. П. Професійно-педагогічна комунікація: [навч. посіб.] / Н. П. Волкова. - К. : Академія, 2006. - 256 с. 6. Кан-Калик В. А. Педагогическое творчество / В. А. Кан-Калик, Н. Д. Никандров. - М.: Педагогика,1990. - 144 с. 7. Коломинский Я. Л. Психология общения / Я. Л. Коломинский.- М. : Знание, 1974. - 96 с. 8. Коммуникативность общения в практику работы школы / под ред. И. Е. Пассова. - М. : Просвещение, 1985. - 127 с. 9. Леонтьев А. А. Психология общения / А. А. Леонтьев. - М. : Смысл, 1997. - 365 с. 10. Ломов Б. Ф. Категории общения и деятельности в психологии / Б.Ф. Ломов // Вопросы философии.- 1979. - № 8. - С. 34-47. 11. Максименко С. Д. Технологія спілкування (комунікативна компетентність учителя: сутність $\mathrm{i}$ шляхи формування) / С. Д. Максименко, М. М. Забродський.- К. : Главник, 2005. - 112 с. 12. Петровский А. В. Личность. Деятельность. Коллектив / А. В. Петровский. - М. : Политиздат, 1982. - 255 с. 13. Рыданова И. И. Основы педагогического общения / И. И. Рыданова. - М. : Белорусская наука, 1998. - 319 с.

УДК $366.362: 378$

І. Г. Максименко, кандидат пед. наук, дочент,

Т. Л. Шепеленко,

кандидат пед. наук,

Криворізький економічний інститут

ДВНЗ «Криворізький національний університет»

\section{ТЕОРЕТИКО-МЕТОДИЧНІ ЗАСАДИ ФОРМУВАННЯ КОМУНІКАТИВНИХ УМІНЬ СТУДЕНТІВ У ПРОЦЕСІ ВИВЧЕННЯ ПСИХОЛОГО-ПЕДАГОГІЧНИХ ДИСЦИПЛІН}

Максименко І. Г., Шепеленко Т. Л. Теоретико-методичні засади формування комунікативних умінь студентів у процесі вивчення психолого-педагогічних дисциплін.

У статті обгрунтовуються сутність, зміст, структура комунікативних умінь та визначаються теоретичні і методичні основи їх формування в процесі вивчення психолого-педагогічних дисциплін.

Ключові слова: уміння, навичка, комунікативні вміння, теоретико-методичні засади.

Максименко И. Г., Шепеленко Т. Л. Теоретико-методические основы формирования коммуникативных умений студентов в процессе изучения психолого-педагогических дисциплин

В статье обосновываются сущность, содержание, структура коммуникативных учений, определяются теоретические и методические основы их формирования в процессе изучения психолого-педагогических дисциплин.

Ключевые слова: умение, навык, коммуникативные умения, теоретико-методические основы.

Maksymenko I. G., Shepelenko T. L. Theoretical and methodological foundations of forming of students' communicative skills while learning psychological and pedagogical disciplines.

The article substantiates the nature, content, structure of communicative skills. It also defines theoretical and methodological principles of their formation while learning psychological and pedagogical disciplines.

Key words: skills, communicative skill, theoretical and methodological foundations. 
Перехід до ринкових умов господарювання супроводжується значними змінами у взаємовідносинах між учасниками педагогічної діяльності, що вимагає від майбутніх фахівців глибокої інтеграції фундаментальних теоретичних знань i сформованих практичних умінь роботи з людьми. Здатність до організації людського чинника $\epsilon$ нині одним із найважливіших показників ефективності професійної діяльності.

Особливого значення в цих умовах набуває проблема якості підготовки майбутніх педагогів. Доведено, що серед чинників, які детермінують ефективність формування всіх підструктур професійної діяльності, систематизуючим визначено комунікативну компетентність спеціаліста, провідним складником якої є комунікативні вміння.

Комунікативні вміння, виражаючи спрямованість дій суб'єкта не на об'єкт, а на інших суб'єктів, створюючи соціально-психологічну основу взаємодії, дозволяють особистості швидко долучатися до професійної діяльності і забезпечувати ії якісний результат. Тому питання формування комунікативних умінь студентів відносять до найбільш актуальних проблем сучасної педагогічної науки і практики і $є$ активно досліджуваними.

Загальні теоретичні положення щодо комунікативної підготовки майбутніх фахівців розглядаються у роботах філософів (Б. Ананьєв, Г. Андрєєва, О. Леонтьєв, С. Рубінштейна та ін), психологів (О. Бодальов, Л. Виготський, Н. Кузьміна та ін.), педагогів (В. КанКалик, Л. Рувинський, Р. Хмелюк та ін.). Формування комунікативних умінь студентів досліджується в різних аспектах: розроблення системного підходу до формування комунікативних умінь (В. Каплинський, Л. Савенкова та ін.), методика навчання студентів комунікативних умінь (Л. Петровська, Т. Яценко та ін.), формування комунікативних умінь студентів у навчально-виховному процесі (А. Алексюк, Л. Рувинський та ін.).

Проте проблема формування комунікативних умінь у майбутніх педагогів у процесі вивчення психолого-педагогічних дисциплін не знайшла належного відображення в наукових дослідженнях.

Mema cmammi - конкретизувати понятійний апарат проблеми формування комунікативних умінь, обгрунтувати теоретико-методичні засади їх формування.

Аналіз психолого-педагогічної літератури свідчить про варіативність підходів до проблеми сутності комунікативних умінь, яка зумовлена неоднозначністю розв'язання питання взаємозв'язку понять «уміння» й «навичка». Одні дослідники (Т. Ільїна, Е. Кабанова-Меллер, Г. Костюк та ін.) уважають навичку дією вищого утворення, а уміння відносять до початкового етапу оволодіння дією. Так, на думку Г. Костюка, уміння - це не цілком завершена навичка, а лише один із етапів його формування [9].

Інша позиція на природу вміння і його взаємозв’язок з навичкою грунтується на тому, що уміння - це опанування такою дією, яку треба здійснювати не автоматично, а 3 творчим використанням знань і навичок $[15$, с. 48$]$, здатність людини цілеспрямовано i творчо використовувати свої знання і навички в процесі практичної діяльності [1, с. 9], вияв дії у всіх можливих варіантах [3, с. 135], вияв дії в нових умовах [13, с. 100].

Аналіз запропонованих підходів дозволяє визначити характерні ознаки уміння: уміння - це утворення більш високого рівня, ніж навичка; основними властивостями уміння $\epsilon$ усвідомленість, узагальненість, гнучкість, що надає змогу індивіду швидко переходити від одного способу дії до іншого, урізноманітнювати прийоми дії, що так необхідно в комунікативній діяльності.

Нам імпонує позиція науковців, які визначають уміння як опанований суб'єктом спосіб виконання дії, що забезпечується сукупністю здобутих знань і навичок, свідомої регуляції і контролю. Ці загальні положення повною мірою стосуються процесу формування всіх видів умінь.

Аналіз психолого-педагогічної літератури свідчить про існування варіативності підходів до проблеми сутності комунікативних умінь.

Так, Н. Кузьміна визначає комунікативні вміння як уміння встановлювати правильні взаємини і перебудовувати їх відповідно до розвитку особистості [10]. С. Бондаренко розуміє їх як уміння впливати на особистість передовсім словом [4]. Н. Косова розглядає 
комунікативні вміння як узагальнений критерій сформованості комунікативної активності на поведінковому рівні, як способи моделювання процесу спілкування і його регуляції [8]. Зазначене вище дозволяе підійти до розуміння комунікативних умінь як інтегративної властивості, яка набута на основі раніше засвоєних знань, навичок і виявляється у здатності виконувати комунікативну діяльність у нових умовах.

Визначення необхідної і достатньої для здійснення ефективної професійної діяльності сукупності комунікативних умінь зумовлює доцільність аналізу наукових досліджень, у яких здійснено спробу описати, класифікувати і подати комунікативні вміння в певній системі.

Так, О. Леонтьєв визначає як провідні такі комунікативні уміння: уміння управляти своєю поведінкою; якості уваги, особливо такі, як спостережливість, гнучкість, переключення; уміння соціальної перцепції або «читання по обличчю»; уміння розуміти, а не тільки бачити, тобто адекватно моделювати особу, іï психічний стан - емпатія; уміння мовного спілкування; уміння мовного і немовного контакту [12].

Л. Єршова у своєму дослідженні акцентує увагу на уміннях «правильно сприймати за виразом обличчя, за рухами, діями і вчинками, а також мовними реакціями людини іiі психічний стан і емоційні переживання; уміння швидко прораховувати різного роду реакції індивіда на ту або іншу педагогічну дію і перебудовувати свої дії, поведінку на основі отриманої інформації; уміння спостерігати, «бачити» i швидко оцінювати педагогічні ситуації, труднощі у своїй діяльності і діяльності учнів» [6, с. 4].

У низці робіт досліджуються окремі комунікативні вміння. Велику увагу науковці приділили вмінню соціальної перцепції [2; 5; 11]. Особливе місце серед цих робіт займають дослідження О. Бодальова. Під час спілкування людини 3 іншими людьми, підкреслює дослідник, у неї виявляється більшою чи меншою мірою вироблене суспільством уміння «читати» експресію, психологічно тлумачити поведінку людей, співпереживати їм, давати їм оцінку [2].

Для успішності спілкування мало знати щось про співбесідника: ураховуючи, що він теж моделює того, хто говорить, важливо надати йому потрібний для цього «матеріал», тобто показати себе в потрібному плані [12, с. 193]. Тому ефективність комунікації багато в чому залежить не тільки від того, як людина сприймає іншого, але й від того, як інші сприймають iii, тобто від уміння самопрезентації. О. Леонтьев зазначає: «Зворотною стороною соціальної перцепції виступає «самоподача» [12, с. 193].

Чільне місце в багатьох дослідженнях (Ф. Гоноболін, І. Зимня, А. Макаренко, О. Леонтьєв, В. Сухомлинський та ін.) посідає проблема формування в індивіда уміння володіти словом як професійним умінням виражати просто і логічно свої думки, говорити переконливо, здійснювати максимально ефективну дію на учасників спілкування, спонукаючи їх до активної мовної взаємодії.

Суттєвий внесок у розв'язання проблеми мовної майстерності забезпечують роботи, у яких особливе місце відведено емоційній виразності мови. С. Рубінштейн зауважує, що емоційність мови може здійснити на іншого належний емоційний вплив, у якому вона не переривається, а виражається відповідно до свідомих намірів того, хто говорить [14, с. 45].

Значну роль у комунікативній діяльності відіграють уміння невербального контакту, які $\epsilon$ зовнішньою формою вияву спрямованості, інтересів, настанов, рівня професіоналізму фахівця (Ю. Смельянов, В. Лабунська, С. Рубінштейн та ін.). С. Рубінштейн пише: «Виразні рухи і виразні дії створюють образ дійової особи, розкриваючи ії внутрішній зміст у зовнішній дії, вони - мова, позбавлена слова, але сповнена експресії» [14, с. 161162]. Невербальні уміння, на думку Ю. Смельянова, виражають не стільки те, що людина думає (для цього вона використовує вербальні засоби), скільки те, що і як вона відчуває [5]. На думку В. Лабунської, уміння особи виражати себе через невербальні засоби, адекватно інтерпретувати невербальну поведінку партнера по спілкуванню, утворюють іiі невербальну поведінку, яка характеризується як соціально і біологічно зумовлений спосіб організації засвоєних індивідом невербальних засобів спілкування [11], перетворених на 
індивідуальну, конкретно-чуттєву форму дій і вчинків.

Ураховуючи позиції дослідників щодо викладених підходів до структури комунікативних умінь, спираючись на основні підструктури комунікативної діяльності, до яких значна частина дослідників (Б. Ананьєв, Г. Андреєва, Я. Коломинський, І. Кон та ін.) відносять перцептивну, експресивну, інтерактивну підструктури, нами виокремлено й об’єднано в групи основні комунікативні вміння, представлені у трьох підструктурах:

- перцептивні уміння (уміння сприймати, розуміти, адекватно моделювати партнера по спілкуванню й емоційно ідентифікувати себе з ним, швидко реагувати на зміни в його поведінці, оцінювати педагогічну ситуацію і перебудовувати способи діï);

- експресивні уміння (володіти зовнішніми засобами виразності, голосом, виразністю мовлення, триматися перед аудиторією, управляти емоційним станом та створювати творче робоче самопочуття);

- інтерактивні уміння (оптимально будувати мовлення, кодувати і конструювати зміст інформації, знаходити адекватні вербальні і невербальні засоби впливу на партнера, установлювати діловий та емоційний контакти, переконувати, ставити запитання, здійснювати рефлексивне і нерефлексивне слухання).

Отже, теоретичний аналіз свідчить, що дослідники приділяють значну увагу проблемі сутності, змісту і структури комунікативних умінь. Однак, практика свідчить, що за наявності значних потенційних комунікативних можливостей психолого-педагогічних дисциплін, зверненість до проблеми формування комунікативних умінь студентів у навчальному процесі $\epsilon$ незначною. Акцентуючи основну увагу на оволодінні фаховими знаннями, вміннями і навиками, переважна більшість викладачів залишає поза увагою комунікативний аспект майбутньої професійної діяльності, що зумовлює виникнення суперечностей між:

- фундаментальною теоретичною освіченістю випускників університету і недостатнім рівнем їх підготовки до комунікативної діяльності;

- між потенційними комунікативними можливостями психолого-педагогічних дисциплін і неможливістю їх ефективної реалізації традиційними формами i методами навчання.

Розв'язання цих суперечностей потребує переходу від концепції жорсткого авторитарного управління навчально-пізнавальною діяльністю студентів до стимулювання їхньої пізнавальної самодіяльності й активності, що потребує внесення суттєвих коректив до навчального процесу.

Виходячи із положення, що уміння - це «поєднання знань, навичок, досвіду і творчих можливостей людини» [7, с. 26], можемо констатувати, що успішність формування комунікативних умінь залежить від півня оволодіння студентами професійними знаннями. Але знання стануть основою способу дії тільки тоді, коли вони будуть усвідомлюватися особистістю, коли будуть мати для неї «особистісний суб'єктивний смисл». Дієвість знань передбачає переживання їх істинності, потребу в їх практичній реалізації (О. Леонтьєв), тому не повинні нав'язуватися студентам у формі готових істин, а засвоюватися в процесі самостійної активної пізнавальної діяльності. Формування умінь вимагає, крім теоретичних знань, також засвоєння «прагматично-процедурних знань» (М. Яровий), тобто знань методів i прийомів теоретичних i практичних дій, які постають алгоритмічними приписами для закріплення навичок.

Засвоєні знання $\epsilon$ основою для формування навичок. Оволодіння навичкою на репродуктивному рівні призводить до «консервування» прихованого потенціалу активності особистості, що не дозволяє їй вийти за межі обставин, які склалися. Але автоматизації в навичці підлягають не всі дії, а тільки ті, які відповідають більш чи менш постійним умовам діяльності. Усі інші дії знаходяться під контролем свідомості, який настільки згорнутий, що виникає ілюзія його повної відсутності [7, с. 13].

Під час формуванні навичок необхідно грунтуватися на твердженні про те, що навичка, характеризуючись стійкістю, вирізняється і певною гнучкістю, тобто зміною в певних 
межах способів дії при зміні умов їх виконання. Чим різноманітніші умови використання навички, тим більшу гнучкість вона має [9].

Щоб досягти цього, необхідно формувати свідому дію як спроектовану, передбачену, засновану на усвідомленні мети, способів іiі виконання. Але дія, перш ніж бути матеріалізованою, тобто відобразитися в поведінковому компоненті, повинна спочатку моделюватися у свідомості. Тобто формування комунікативних умінь вимагає свідомого поєднання знань і навичок шляхом моделювання уявного образу дії і тільки потім вибору адекватного цій моделі способу дії, що забезпечує перехід від механічного переносу навичок до творчого їх використання.

Виходячи із вище викладеного, логіка й основні позиції методики формування комунікативних умінь будуються на основі трьох етапів: 1) засвоєння теоретичних знань сутності та змісту комунікативних умінь, знань про способи теоретичних та практичних дій і формування уявної моделі цих дій; 2) оволодіння системою навичок як автоматизованих компонентів реалізації уявної моделі дії; 3) формування досвіду переносу засвоєних навичок у нові ситуації, які вимагають їх творчого застосування.

Отже, можемо зробити висновок, що ефективне оволодіння комунікативними вміннями забезпечується засвоєнням теоретичних і теоретико-процедурних знань і сформованих відповідних навичок та їх усвідомленого і творчого застосування в навчальному процесі вищої школи.

\section{Література}

1. Барабанщиков Л. В. Педагогические основы обучения советских воинов / Л. В. Барабанщиков. - М.: Воениздат, 1962. - 152 с. 2. Бодалев А. А. Восприятие и понимание человека человеком / А.А. Бодалев. - М. : Изд-во МГУ, 1982. - 200 с. 3. Бойко Е. И. Еще раз об умениях и навыках / Е. И. Бойко // Вопросы психологии. - 1957. - № 1. - С. 133-139. 4. Бондаренко С. Л. Оптимизация коммуникативной деятельности учителя на уроке: автореф. дис. на соискание уч. степени канд. психол. наук: спец. 19.00.01 / С.Л. Бондаренко - К., 1976. - 23 с. 5. Емельянов Ю. Н. Обучение паритетному диалогу: [учеб. пособ.] / Ю. Н. Емельянов.-Л. : Изд-во ЛГУ, 1991. - 106 с. 6. Ершова Л. Д. Особенности восприятия учителем личности учащихся / Л. Д. Ершова.- Л. : Изд-во ЛГУ, 1978. - 157 с. 7. Кисельгоф С. И. Формирование у студентов педагогических умений и навыков в условиях университетского образования / С. И. Кисельгоф. - Л.: Изд-во ЛГУ, 1973. - 152 с. 8. Косова Н. М. Формирование коммуникативной активности будущего учителя: дис....кандидата психол. наук: спец.19.00.07 / Н. М. Косова. - М., 1988. - 258 с. 9. Костюк Г. С. Исследования по проблеме обучения и развития / Г. С. Костюк // Сов. педагогика. 1964. - № 5. - С. 148-151. 10. Кузьмина Н. В. Очерки психологии труда учителя. Психологическая структура деятельности учителя и формирование его личности / Кузьмина Н.В. - Л.: Изд-во ЛГУ, 1967. -184 с. 11. Лабунская В. А. Невербальные средства общения / В. А. Лабунская - Ростов : Издво Рост. ун-та, 1979. -135 с. 12. Леонтьев А. А. Психология общения / А. А. Леонтьев - М.: Смысл, 1997. - 365 с. 13. Платонов К. К. О знаниях, навыках и умениях / К. К. Платонов // Сов. педагогика. - 1963. -№11. - С. 98-103. 14. Рубинштейн С. Л. Основы общей психологии / С. Л. Рубинштейн. М. : Педагогика, 1989. - Т.1. - 485 с. 15. Спирин Л. Ф. Формирование профессиональнопедагогических умений учителя- воспитателя / Л. Ф. Спирин - Ярославль, 1976. -82 с. 